\title{
Coronavirus Pandemic as Black Swan Event
}

\author{
Tatiana Antipova ${ }^{(凶)}(\mathbb{D}$ \\ Institute of Certified Specialists, Perm, Russia \\ fakademia@mail.ru
}

\begin{abstract}
Nowadays coronavirus is the hottest break news around the world. This paper aims to study why coronavirus became so meaningful for worldwide life. On one side many countries closed their boarders to prevent coronavirus spreading. On another side some people said that coronavirus is no scared than simple influence. Where is true? The health effects and mortality of coronavirus and influenza were compared. Situation Reports of World Health Organization have been analyzed and signs of Black Swan event considered. Total confirmed cases, total, deaths, and Rate of coronavirus distribution was calculated based on Situation Reports of the World Health Organization. To conclude this paper Coronavirus Pandemic recognized as Black Swan event according to considered figures and facts from recent references.
\end{abstract}

Keywords: Coronavirus $\cdot$ COVID-19 $\cdot 2019$-nCov $\cdot$ Black Swan event $\cdot$ Economy impact - Social impact · Housing Boom · Coronavirus impact · Financial consequences $\cdot$ Collapse $\cdot$ Coronavirus Pandemic

\section{Introduction}

There is a worldwide concern about the new coronavirus 2019-nCoV as a global public health threat [1]. The 2019-nCoV infection is spreading and its incidence is increasing worldwide. Although the current mortality is lower than that of the SARS-CoV and the MERS-CoV, it seems that the 2019-nCoV is very contagious. SARSCoV (severe acute respiratory syndrome coronavirus) was recognized in November 2002, MERS-CoV (Middle East respiratory syndrome coronavirus) in June 2012, and 2019-nCoV in December 2019 [2]. The first deaths occurred mostly in elderly people, among whom the disease might progress faster [3]. But now it established that the young people are also prone to severe coronavirus disease so the society should still be cautious in dealing with the virus and pay more attention to protecting all of people from the virus.

Coronavirus (COVID-19) spread worldwide with the pandemic according to data of World Health Organization (WHO). Since Coronavirus is spreading very fast, 11.03.2020 WHO Director-General's characterized Coronavirus as a pandemic and this pandemic has the social and economic impacts [5, report 51, 71].

There are signs that governments' authorities are still trying to conceal the true scale of the problem with Coronavirus, but at this point the virus appears to be more contagious than the pathogens behind diseases such as Ebola or SARS - though some experts say SARS and coronavirus are about equally contagious. Events like the coronavirus epidemic, and its predecessors - such as SARS, Ebola and MERS - test 
Health Care systems and force us to think about the unthinkable. What national and international systems need to be in place to minimize the chance of catastrophe on this scale? So far, the 21 st century has been an age of black swans. That age isn't over, and of the black swans still to arrive, the coronavirus epidemic is unlikely to be the last to materialize around the world [6].

Taleb, in his book [21], coined the term "black swan" to describe random events that form part of our lives. These events have the following three key attributes/signs: (1) outlier, being outside the realm of regular expectations; (2) carries an extreme impact; and (3) explanations for the occurrence are concocted after the fact, making it explainable and predictable.

In identifying the attributes, the classification of a black swan event appears to depend on individual interpretation. Such events are large-scale shocks which can severely challenge economic activity, social cohesion and even political stability. These different patterns of risk can cascade and spread across global systems, where they arise in health, climate, social or financial systems [20]. For example, infectious virus such Bird Flu, Asia (2008) and SARS, Hong Kong (2002) were recognized as Black Swan events by D. Higgins [20].

This paper considers some signs of coronavirus impact in following part.

\section{Nature of Coronavirus}

On 31 December 2019, the WHO Country Office in China was informed of cases of pneumonia with unknown etiology (unknown cause) found in Wuhan City, Hubei Province, China. No causal link was established from 31 December 2019 to 3 January 2020. One week later the World Health Organisation (WHO) received further details from the Chinese National Public Health Commission that the outbreak was linked to radiation at a seafood market in Wuhan City. And then Chinese authorities identified a new type of coronavirus that had been isolated on 7 January 2020. The name "coronavirus" was given because this virus visually looks like it is surrounded by a crown. It has been officially named COVID-19. The virus affecting people now is what's called a novel coronavirus ( $\mathrm{nCoV}$ ) because it's the first time this particular strain is being seen in humans. So, we have two officially medical abbreviations for Coronavirus: COVID19 and 2019-nCoV (for laboratory tests).

As coronavirus cases continue to be reported around the world, WHO says countries still have a chance of containing the outbreak. Officials have also sought to differentiate Covid-19 from other viruses, as part of efforts to quell public panic. People want to know the answer on two simple questions: "What is coronavirus?" and "What makes COVID-19 different to influenza?" 
What is coronavirus?

For COVID-19, data to date suggest that $80 \%$ of infections are mild or asymptomatic, $15 \%$ are severe infection, requiring oxygen and $5 \%$ are critical infections, requiring ventilation. These fractions of severe and critical infection would be higher than what is observed for influenza infection. Those most at risk for severe influenza infection are children, pregnant women, elderly, those with underlying chronic medical conditions and those who are immunosuppressed [5].

According to "Contacts investigation protocol for coronavirus disease 2019 (COVID19)" (https://www.who.int/publications-detail/the-first-few-x-(ffx)-cases-and-contactinvestigation-protocol-for-2019-novel-coronavirus-(2019-ncov)-infection) WHO listed following symptoms: Fever $\left(>38^{\circ} \mathrm{C}\right)$; Sore throat; Runny nose; Shortness of breath, Chills; Nausea; Diarrhoea; Headache; Rash; Conjunctivitis; Muscle aches; Joint ache; Loss of appetite; Nose bleed; Fatigue; Seizures; Altered consciousness. Some of those symptoms are illustrated on Fig. 1.

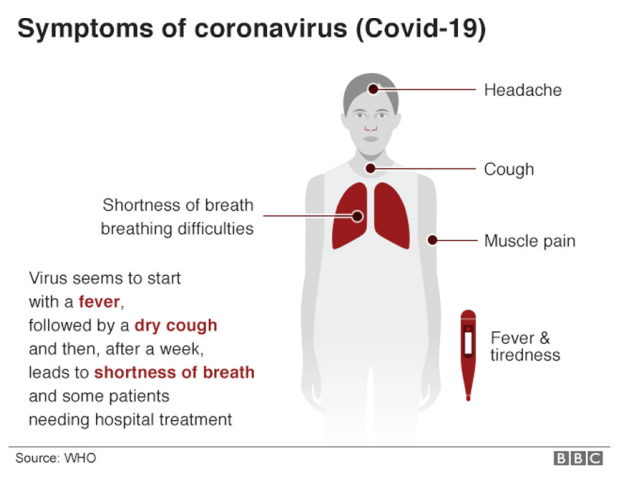

Fig. 1. Symptoms of coronavirus.

What makes COVID-19 different to influenza?

As the COVID-19 outbreak continues to evolve, comparisons have been drawn to influenza. Both cause respiratory disease, yet there are important differences between the two viruses and how they spread. This has important implications for the public health measures that can be implemented to respond to each virus [5].

Let's consider similarities and differences between COVID-19 and Influenza. The result of this comparison is shown in Table 1. 
Table 1. Similarities and Differences between COVID-19 and Influenza.

\begin{tabular}{|c|c|}
\hline Similarities & Differences \\
\hline $\begin{array}{l}\text { They both cause respiratory disease, which } \\
\text { presents as a wide range of illness from } \\
\text { asymptomatic or mild through to severe } \\
\text { disease and death }\end{array}$ & $\begin{array}{l}\text { Influenza has a shorter median incubation } \\
\text { period and a shorter serial interval than } \\
\text { COVID-19 virus. The serial interval for } \\
\text { COVID-19 virus is estimated to be } 5-6 \text { days, } \\
\text { while for influenza virus, the serial interval is } 3 \\
\text { days. This means that influenza can spread } \\
\text { faster than COVID19 }\end{array}$ \\
\hline \multirow[t]{3}{*}{$\begin{array}{l}\text { Both viruses are transmitted by contact, } \\
\text { droplets and fomites }\end{array}$} & $\begin{array}{l}\text { The reproductive number for COVID- } 19 \text { is } \\
\text { higher than for Influenza- is understood to be } \\
\text { between } 2 \text { and } 2.5 \text { for COVID- } 19 \text { virus }\end{array}$ \\
\hline & $\begin{array}{l}\text { Children are important drivers of influenza } \\
\text { virus transmission in the community. For } \\
\text { COVID-19 virus, children are infected from } \\
\text { adults, rather than vice versa }\end{array}$ \\
\hline & $\begin{array}{l}\text { Mortality of COVID-19 is between } 3-5 \% \text {, but } \\
\text { for seasonal influenza, mortality is usually well } \\
\text { below } 0.1 \%\end{array}$ \\
\hline
\end{tabular}

Source: Author's elaboration based on $46^{\text {th }}$ WHO Situation Report [5].

So, we can see that COVID-19 and Influenza have similar symptoms, but transmissions but COVID-19 is more scared with higher Mortality. Strangely, perhaps, the most effective general procedure for stopping an outbreak from becoming a full-fledged pandemic is simple common sense; in other words, education about elementary procedures for health care and sanitation. For example, wash your hands when handling food, keep your home and outdoor areas clean, properly take medications. Such procedures go a very long way toward stopping infectious diseases in their tracks [22].

\section{Coronavirus Spreading}

WHO daily reports incidence of confirmed 2019-nCoV cases on https://www.who.int/ emergencies/diseases/novel-coronavirus-2019/situation-reports/. The first Situation Report was dated as 20.01.2020. The author has analyzed some selection WHO situation reports to define trend of Coronavirus spreading. As a result of those reports' study, total numbers of registered cases of Coronavirus infection and total deaths are shown on Fig. 2. 


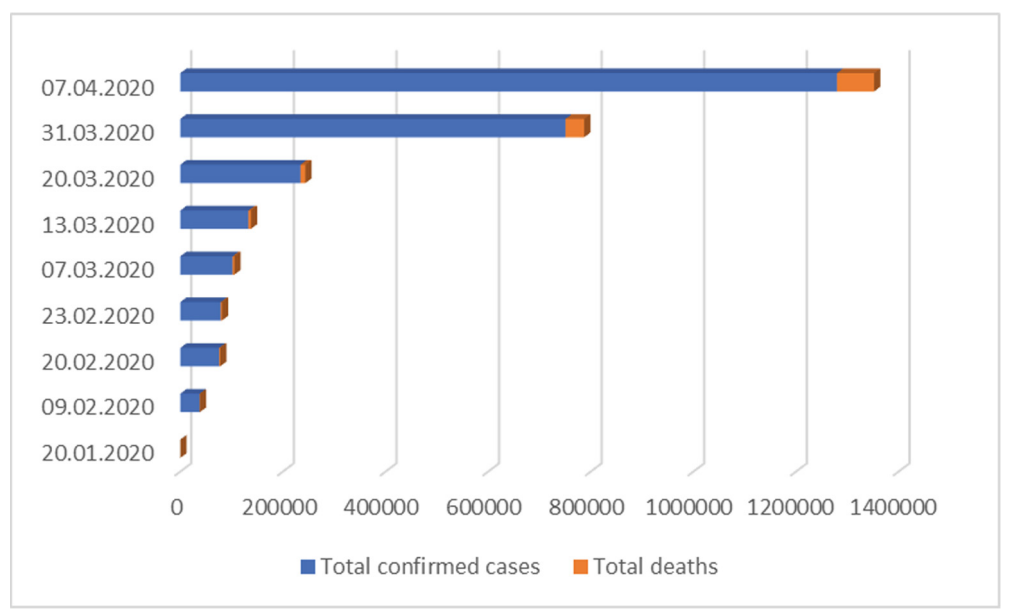

Fig. 2. Total confirmed cases of coronavirus infection causing total deaths. Source: Author's analysis based on WHO Situation Reports [5]: 1-77.

To date (Fig. 2), the total number of confirmed coronavirus cases globally topped over 1200,000 (1 279722 as of 07.04.2020), causing 72614 deaths as of 07.04.2020. During the study period (20.01.2020-31.03.2020), the coronavirus covered 205 Countries/Territories/Areas with average rate of about 10441 people per day for 78 days (20.01.2020-07.04.2020). But the good news is that more than 56,000 people are now free of the virus in China. So, around $70 \%$ of coronavirus patients in China have recovered, as per the recent $\mathrm{WHO}$ report.

As shown above, Coronavirus became very widespread, so we can see economic and social impacts. If people become very worried that they can catch the disease if they go out in public, this will mean many fewer people will go to restaurants, sports events, movie theaters and concerts, or anyone else where they are likely to be in close proximity to large numbers of people. Many of these businesses are likely to shut down, at least until the major threat of the virus has passed [9].

Mortality of Coronavirus is shown on Fig. 3 and we can see that maximum Mortality of COVID-19 is 5,7\% (Share of Total deaths in Total confirmed cases).

Graph on Fig. 3 shows that Mortality of COVID-19 increased from 1,1 to 5,7\% just for 78 days and nobody knows when and at what magnitude will stop growing yet.

Covid-19 is spreading from China to other regions causing human suffering, economic disruption, and Globalization. Some people said that if their country did not get foreigners from abroad, coronavirus would never come inside their country. It is raising health concerns and the risk of wider restrictions on the movement of people, goods and services, falls in business and consumer confidence and slowing production. The Interim Outlook presents both a best-case scenario in which the extent of the 


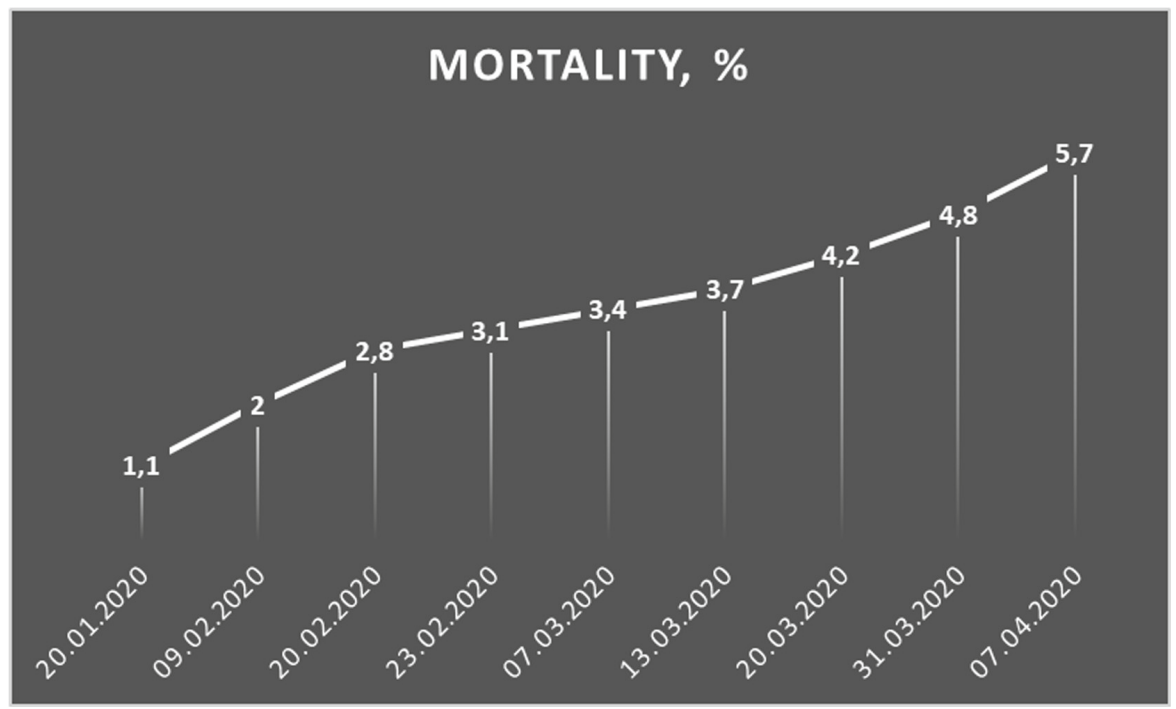

Fig. 3. Mortality of Coronavirus. Source: Author's analysis based on WHO Situation Reports [5].

coronavirus is broadly contained and a "domino" prospect of contagion that is more widespread. In both cases, it is reasonable to call governments to act immediately to limit the spread of the coronavirus, protect people and businesses from its effects and shore up demand in the economy. One possible way to protect people from unreasonable decision is using patented method of identification/authentication of citizens [11].

\section{Coronavirus Social and Economic Impacts}

The novel coronavirus (Covid-19) is a major global public health emergency that has brought tragedy to many lives. Its impact is still unfolding globally. There is already a major slowdown in the wider economy around the world [25]. Many now fear the coronavirus will become a global pandemic. The consequences of a Chinese economic meltdown would travel with the same sweeping inexorability. Commodity prices around the world would slump, supply chains would break down, and few financial institutions anywhere could escape the knock-on consequences. Recovery in China and elsewhere could be slow, and the social and political effects could be dramatic [8].

Businesses are dealing with lost revenue and disrupted supply chains due to China's factory shutdowns, tens of millions of people remaining in lockdown in dozens of cities and other countries extending travel restrictions. The shortage of products and parts from China is affecting companies around the world, as factories delayed opening after the Lunar New Year and workers stayed home to help reduce the spread of the virus. Apple's manufacturing partner in China, Foxconn, is facing a production delay. Some carmakers including Nissan and Hyundai temporarily closed factories outside 
China because they couldn't get parts. The pharmaceutical industry is also bracing for disruption to global production. Many trade shows and sporting events in China, Asia and across the world have been cancelled or postponed [26].

Today, it is central to global supply chains and there has been an enormous increase in travel to and from the country, thus heightening the risk of the virus spreading [25]. It means that the tourism and travel industry have suffered from the coronavirus outbreak. Plane travel has been dramatically reduced, as few people would want to be in a crowded plane that could house several people with the virus. This is a huge blow to the tourism industry as people are putting off their holidays until the epidemic subsides [9]. Global airline revenues are expected to fall by $\$ 4-5$ billion in the first quarter of 2020 as a result of flight cancellations, according to a report from the UN's International Civil Aviation Organization (ICAO). ICAO also forecasts that Japan could lose $\$ 1.29$ billion of tourism revenue in the first quarter due to the drop in Chinese travelers while Thailand could lose $\$ 1.15$ billion [26].

The consequences of Covid-19 for global oil demand will be significant. Demand is now expected to contract by $435 \mathrm{~kb} / \mathrm{d}$ in Q20, the first quarterly decrease in more than a decade. For 2020 as a whole, we have reduced our global growth forecast by $365 \mathrm{~kb} / \mathrm{d}$ to $825 \mathrm{~kb} / \mathrm{d}$, the lowest since 2011. Growth in 2019 has been trimmed by $80 \mathrm{~kb} / \mathrm{d}$ to $885 \mathrm{~kb} / \mathrm{d}$ on lower-than-expected consumption in the OECD [25].

The impact of Covid-19 for oil prices have been sharp (see Table 2). Before Covid19 came along, crisis the market was expected to move towards balance in the second half of 2020 due to a combination of the production cuts implemented at the start of the year, stronger demand and a tailing off of non-OPEC supply growth. Now, the risk posed by the Covid-19 crisis has prompted the OPEC+ countries to consider an additional cut to oil production of $0.6 \mathrm{mb} / \mathrm{d}$ as an emergency measure on top of the 1.7 $\mathrm{mb} / \mathrm{d}$ already pledged. The effect of the Covid-19 crisis on the wider economy means that it will be difficult for consumers to feel the benefit of lower oil prices [25].

The Table 2 represents some signs of social and economic impacts of Coronavirus Pandemic.

Table 2 demonstrates that Chinese and Indian GDP tend to decrease on 1.5 and $2.1 \%$ respectively, oil consumption and price fell to lower-than-expected amounts. So, worldwide outbreak plus the fall of important economic indicators such: Global Trade, Economy, Housing Boom, Fuels and energy, Finance, GDP, Global Economic shows the significant consequences of Coronavirus spreading, which proves the possibility of recognizing it as Black Swan event. This event has severely challenge economic activity and social cohesion.

Prospects for a big hit to the economy and the spread of Covid-19 to hundreds of countries have chilled financial markets, government planners and corporate executives. In March 2020 a plunge in Chinese factory output is expected to destroy the disease disrupted supply chains - with damaging consequences for companies around the world. China's Commerce Ministry this week said $90 \%$ of the 7,000 exporters it surveyed reported difficulty shipping goods, as counterparts cancel contracts or don't pay. The country's largest steelworks, China Baowu Steel Group Corp., predicted a first-quarter loss of $\$ 428$ million. [19] At the same time China’s president Xi Jinping warned that the coronavirus would have a "relatively big impact on the economy and society". Adding that it would be short-term and controllable, Xi said the government 
Table 2. Signs of belonging Coronavirus Pandemic to Black Swan event

\begin{tabular}{|c|c|}
\hline Signs & Coronavirus impact/consequences \\
\hline $\begin{array}{l}\text { Global economic } \\
\text { growth }\end{array}$ & $\begin{array}{l}\text { Dun \& Bradstreet estimates in a new report that if a vaccine for the virus } \\
\text { is not invented by the second quarter of } 2020 \text {, and containment of the } \\
\text { disease is therefore delayed until the fourth quarter or beyond, the } \\
\text { global economic cost could be as much as a one-percentage-point } \\
\text { slowdown in global economic growth [12] }\end{array}$ \\
\hline $\begin{array}{l}\text { Global trade } \\
\text { indicators }\end{array}$ & $\begin{array}{l}\text { Canada's deficit in the global trade of merchandise goods widened in } \\
\text { January, to } 1.47 \text { billion Canadian dollars ( } \$ 1.10 \text { billion) from } C \$ 732 \\
\text { million in the previous month, on a broad-based drop in exports to both } \\
\text { the U.S. and China. Exports of goods fell } 2 \% \text { in January, to C } \$ 48.14 \\
\text { billion, or the lowest level in } 11 \text { months. Imports declined } 0.5 \% \text {, and on } \\
\text { a year-over-year basis decreased } 4.9 \% \text {. Exports to China, Canada's } \\
\text { second-largest trading partner, fell } 7.8 \% \text { in January, and } 8.6 \% \text { on a one- } \\
\text { year basis. Imports from China fell by a steeper } 12.1 \% \text { in the month. } \\
{[18] \text { Indian trade proved to be a nightmare for, local markets with }} \\
\text { frontline gauges losing over three and a half percent in a single day after } \\
\text { industry body PHDCCI said that the coronavirus outbreak may } \\
\text { negatively impact global growth by } 30 \text { basis points or } \$ 250 \text { billion [16] }\end{array}$ \\
\hline $\begin{array}{l}\text { Economy } \\
\text { indicators }\end{array}$ & $\begin{array}{l}\text { Commodities-focused companies fell in Tokyo where the Topix shed } \\
0.6 \% \text {. Singapore's FTSE Straits Times dropped } 1.9 \% \text {. Seoul's } \\
\text { benchmark Kospi index closed down } 3.1 \% \text {, with stocks that are } \\
\text { exposed to a probable fall in spending by Chinese tourists as a result of } \\
\text { the virus among the hardest hit. AmorePacific, South Korea's largest } \\
\text { cosmetics company, dropped } 8.5 \% \text { while duty-free chain Hotel Shilla } \\
\text { tumbled almost } 10 \% \text {. Smartphone and chip manufacturer Samsung fell } \\
\text { more than } 3 \% \text {. [7] Five industry sectors-business and personal } \\
\text { services, wholesale trade, manufacturing, retail, and financial services- } \\
\text { account for more than } 80 \% \text { of the businesses within the affected } \\
\text { provinces [12] }\end{array}$ \\
\hline Housing Boom & $\begin{array}{l}\text { New home sales data for January comes out at } 10 \text { a.m. ET and } \\
\text { economists are expecting } 711,000 \text { single-family homes sold last month, } \\
\text { up from } 694,000 \text { in December, according to Dow Jones. This would be } \\
\text { a } 2.4 \% \text { jump in home sales month-over-month [14] }\end{array}$ \\
\hline $\begin{array}{l}\text { Fuels and energy } \\
\text { prices }\end{array}$ & $\begin{array}{l}\text { Brent crude was down } \$ 2.42 \text {, or } 4.1 \% \text {, to } \$ 56.09 \text { a barrel. U.S. crude } \\
\text { futures fell by } \$ 2.12 \text {, or } 4 \% \text {, to } \$ 51.26 \text {. [15] In Sydney the S\&P/ASX } \\
200 \text { index slipped } 1.8 \% \text { as energy and mining stocks sold off on } \\
\text { concerns over the pathogen's impact on Chinese demand. [7] Brent } \\
\text { values fell by about } \$ 10 / \mathrm{bbl} \text {, or } 20 \% \text {, to below } \$ 55 / \mathrm{bbl}[25]\end{array}$ \\
\hline Finance indicators & $\begin{array}{l}\text { Bank of America analysts, for their part, have already downgraded their } \\
\text { eurozone growth prospects for this year, from their previous } 1 \% \text { to } \\
0.6 \% \text {. [6] Gold was down } 0.9 \% \text {. [7] Several major companies including } \\
\text { Apple (ticker: AAPL), Mastercard (MA), and United Airlines Holdings } \\
\text { (UAL) have already warned that they'll be unable to meet prior } \\
\text { financial guidance due to Covid-19. Corporate earnings will be hit, but } \\
\text { the broader economy can still survive a quarter or two of that. [10] The } \\
\text { Dow Jones Industrial Average fell } 12.4 \% \text { last week, its worst showing } \\
\text { since the financial crisis, as fear built that the globalized epidemic will } \\
\text { damage trade and pull the world economy toward recession [19] }\end{array}$ \\
\hline
\end{tabular}


Table 2. (continued)

\begin{tabular}{l|l}
\hline Signs & Coronavirus impact/consequences \\
\hline GDP & $\begin{array}{l}\text { Torsten Sløk, expects the outbreak to shave 1.5\% points off of Chinese } \\
\text { gross domestic product this year (to } 4.6 \% \text { from 6.1\%) and said he } \\
\text { thinks the virus will take a 0.5\% point off of global growth this year. } \\
\text { [17] India's Gross Domestic Product (GDP) growth at 4.5\% for the } \\
\text { third quarter (Q3) of current fiscal year (FY20), which is lower than } \\
6.6 \% \text { GDP growth recorded in the corresponding period a year ago [16] }\end{array}$ \\
\hline Social impacts & $\begin{array}{l}\text { The most of country in lockdown for three weeks and effectively could } \\
\text { be many more, brings several concerns in its wake. First, living in } \\
\text { isolation is difficult, because humans are social creatures. Secondly, fear } \\
\text { and anxiety can take a toll on both young and the old. The young fear } \\
\text { losing a living. The old fear emptiness and a lack of purpose. A research } \\
\text { published in the American Journal of Epidemiology, reports that there is } \\
\text { robust evidence that social isolation and loneliness significantly } \\
\text { increase risk for premature mortality, and the magnitude of the risk } \\
\text { exceeds that of many leading health indicators. This in turn can lead to } \\
\text { difficulties with decision-making and memory storage and recall. They } \\
\text { are also susceptible to illness. Researchers found that a lonely person's } \\
\text { immune system responds differently to fighting vi-ruses, making them } \\
\text { more likely to develop new illness. 1.3 billion people confined to homes } \\
\text { for a month and more can create a new dimension of a yet unfolding } \\
\text { problem for both the health workers and the government [27] }\end{array}$ \\
\hline
\end{tabular}

would step up efforts to cushion the blow. The country has taken a number of measures in recent weeks to prop up its economy [24].

The International Monetary Fund (IMF) forecasts the epidemic will reduce China's economic growth this year by $0.4 \%$ point to $5.6 \%$ [19]. IMF head, Kristalina Georgieva, said that the global lender of last resort was ready to provide additional support, particularly to poorer countries by way of grants and debt relief. Speaking at a G20 meeting of finance leaders and central bank chiefs, she said the IMF assumed the impact would be relatively minor and short-lived, although she warned that the continued spread of the virus could have dire consequences. She added: "Global cooperation is essential to the containment of the Covid-19 and its economic impact, particularly if the outbreak turns out to be more persistent and widespread" [24].

Currently, there is no registered treatment or vaccine for Coronavirus disease unfortunately. In the absence of a specific treatment for this novel virus, there is an urgent need to find an alternative solution to prevent and control the replication and spread of the virus [4]. Since there is no cure for coronavirus yet, the country that will receive this medicine at first may influence world politics. And this is the most important Coronavirus Pandemic impact on world political life.

The social impact of coronavirus can also be attributed to the fact that many countries have closed their borders and introduced quarantine/self-isolation for their 
citizens for one month at least. And people cannot move not only from country to country but leave their own home during quarantine in these countries (most often in March-April 2020). Cultural institutions such as museums, theatres and libraries, etc. have also been closed. Major sporting events have been cancelled or postponed. Thus, the Tokyo Olympics has been postponed by one year.

\section{Conclusions}

As it shown above, Coronavirus Pandemic recognized as Black Swan event according to considered signs from recent references and we can see severely challenges economic activity, social cohesion and even political stability.

To reduce Coronavirus consequences official recommendations from both the Centers for Disease Control and the World Health Organization encourage the use of telemedicine apps. Public companies that offer telemedicine, including Teladoc, have seen their stock surge in the past week, and many private start-ups, from AmericanWell to Plushcare, tell CNBC they are bracing for increased usage [14]. Guidance on how to manage patients with COVID-19 must be delivered urgently to healthcare workers in the form of workshops, online teaching, smart phone engagement, and peer-to-peer education. Equipment such as personal protective equipment, ventilators, oxygen, and testing kits must be made available and supply chains strengthened [23].

As we can see from study result, Coronavirus Pandemic has significant impacts on social and economic life. In forecasting future socio-economic indicators, we will have to make adjustments to the black swan effect, which is Coronavirus Pandemic.

The crisis caused by Coronavirus Pandemic calls on our self-confident technological civilization to assess the limits of its capabilities and to recognize the fragility of this civilization. We have amazing scientific research and its results translated into reality, but we remain very fragile and truly weak. And this crisis shows us today the limitations of our capabilities in order not to give up, not to fall into confusion, but to restrain the pandemic and remain sapiens human.

\section{References}

1. Benvenuto, D., Giovanetti, M., Ciccozzi, A., Spoto, S., Angeletti, S., Ciccozzi, M.: The 2019-new coronavirus epidemic: evidence for virus evolution. J. Med. Virol. 92, 455-459 (2020). https://doi.org/10.1002/jmv.25688

2. Stein, R.A.: The 2019 coronavirus: learning curves, lessons, and the weakest link. Int. J. Clin. Pract. (2020). https://doi.org/10.1111/ijcp.13488

3. Wang, W., Tang, J., Wei, F.: Updated understanding of the outbreak of 2019 novel coronavirus (2019-nCoV) in Wuhan. China J. Med. Virol. 92, 441-447 (2020). https://doi. org/10.1002/jmv.25689

4. Zhang, L., Liu, Y.: Potential interventions for novel coronavirus in China: a systematic review. J. Med. Virol. 1-12 (2020). https://doi.org/10.1002/jmv.25707

5. Coronavirus disease 2019 (COVID-19). Situation Report, pp. 1-77. https://www.who.int/ docs/default-source/coronaviruse/situation-reports/ 
6. Briançon, P.: Are markets putting too much hope in ECB's capacity to help Europe deal with coronavirus crisis? Barron's (2020)

7. Georgiadis, P., Lockett, H., Rocco, M.: US stocks rebound day after coronavirus fears hit markets. FT.Com (2020)

8. Walter, R.M.: China is the real sick man of Asia; its financial markets may be even more dangerous than its wildlife markets. Wall Street J. (2020)

9. Baker, D.: Coronavirus, the Stock Market, and the Economy. Beat the Press [BLOG] (2020)

10. Jasinski, N.: What Comes After the Coronavirus? It Could Be a 'V-Shaped Market'. Barron's (2020)

11. Konyavsky, V., Ross, G.: New method for digital economy user's protection. In: ICIS 2019. LNNS, vol. 78, pp. 221-230 (2020). https://doi.org/10.1007/978-3-030-22493-6_20

12. McCann, D.: Coronavirus Crimps Supply Chains, May Harm World Economy. CFO.Com (2020)

13. Coronavirus watch, earnings, new home sales: 3 things to watch for in the markets on Wednesday. https://www.cnbc.com/2020/02/25/outlook-for-wednesday-coronavirus-watchearnings-new-home-sales.html

14. Anonymous Stock Review: Two-bagger teladoc health jumps $7.8 \%$ on strong volume. News Bites Pty Ltd., Melbourne (2020)

15. Anonymous Stock Review: Baker hughes climbs 4.5\%, issued 9 new patents. News Bites Pty Ltd. Melbourne (2020)

16. Anonymous "Markets witness mayhem as coronavirus pandemic fear intensifies" Accord Fintech (2020)

17. Beilfuss, L.: China's coronavirus data look too good to be true. Barrons 100(7), 35 (2020)

18. Vieira, P.: Canada data offer warning signs on coronavirus; job creation, wage gains continued in February, but trade report for January highlights economic risk posed by epidemic. Wall Street J. (2020)

19. Areddy, J.T.: China's economy reels as coronavirus hits manufacturing worse than financial crisis; the fate of China's economy is of crucial importance to a world with few solid drivers of growth. Wall Street J. (2020)

20. Higgins, D.M.: The black swan effect and the impact on Australian property forecasting. J. Financ. Manag. Property Constr. 18(1), 76-89 (2013)

21. Taleb, N.: The Black Swan: The Impact of the Highly Improbable, 2nd edn. Penguin Book, London (2009)

22. Casti, J.: Four Faces of Tomorrow. OECD International Future Project on Future Global Shocks (2011). https://www.oecd.org/futures/globalprospects/46890038.pdf

23. COVID-19: Too little, too late? EDITORIAL. Lancet 395(10226), 755. https://doi.org/10. 1016/S0140-6736(20)30522-5

24. https://www.theguardian.com/business/2020/feb/23/economic-impact-of-coronavirusoutbreak-deepens

25. https://www.iea.org/reports/oil-market-report-february-2020

26. https://www.weforum.org/agenda/2020/02/coronavirus-economic-effects-global-economytrade-travel/

27. Mantha, S.S.: The cost of corona. Lokmat Times 29(03), 6 (2020) 